\title{
Intelligent Baby Box Based on loT to Observe Room Temperature and Baby Crying
}

\author{
Dani Sasmoko ${ }^{\text {a1 }}$, Dzyo Bachtiar ${ }^{\text {a2 }}$ \\ anformatics Management Department, Sekolah Tinggi Elektronika dan Komputer Pat \\ JI.Majapahit 605 ,Semarang, Jawa Tengah, Indonesia \\ dani@stekom.ac.id \\ ${ }^{b}$ Computer System Department, Sekolah Tinggi Elektronika dan Komputer Pat \\ Jl.Majapahit 605 ,Semarang, Jawa Tengah, Indonesia \\ 2 dzyobachtiar992@gmail.com
}

\begin{abstract}
Internet of Things (IOT) connects a global infrastructure in communities so they can take benefit of advanced services, by connecting objects (things) both physical and virtual with the Internet so that objects can communicate each other. The object of this study is a baby box to control the baby's condition. When the baby cries too long it may cause Baby Distressed Tantrum which is the feeling of being depressed in the baby because they feel ignored. If this happens for a long time will endanger the baby's health as it is related to respiratory function and cardiac performance. The function of the baby box is to observe a baby when left without supervision. It will enable users to know if the baby is sleeping, awake or crying. Leaving a crying baby too long may have a negative effect. By applying the Internet of Things (IOT) in the design of an intelligent a baby box will help the parents and babysitter in controlling the baby if they have other activities to do. The baby box monitoring system has a dht11 temperature and humidity sensor, and a noise sensor to detect the baby crying. An esp8266 module on Wemos d1 will send data to an android smartphone and notify the user by sound or vibration.
\end{abstract}

Keywords: Wemos, dht11, baby, Android, loT (Internet of Things).

\section{Introduction}

Internet of Things (IoT) connects the global infrastructure with the community that allows advanced services, by connecting objects (things) both physical and virtual by Internet technology so that all devices can communicate each other[1]. The physical device in this research is a baby box which is used to observe the condition of the baby especially to observe a baby when left behind without supervision. While baby sleeping then wakes up and cry too long will cause side effects. By applying the Internet of Things (IoT) in the design of an intelligent a baby box will help the parents and babysitter in monitoring the baby while doing other activities and leave the baby out of their sight [2]. Research that related to loT which was applied in the infused tool in a hospital can send a heavy data from the infused tool used esp 8266 tp-01 to database MySQL that was monitored via Web using load cell sensor so that it makes easier to monitored the infused tool [3]. Another research finds that loT technology can send data from more than 1 sensor at the same time. In this research used temperature, smoke and fire sensor and also use Sim 900 to send data to Web based application and using MySql database to save data from Arduino [4]. In one study conducted on baby aged 4-12 months, the result is that when they cry in truth they expect the people around them to entertain and make them laugh and feel comfortable. But if they don't get what they want the effect that arises is Distressed Tantrum which is a feeling of being depressed in toddlers because they feel ignored. If it happens for a long time will endanger the baby's health because it is related to respiratory function and cardiac performance [5]. 
Based on the research above, research with the title "Intelligent Baby Basket Box on loT to monitor Room Temperature and Baby Crying" done for loT technology development by testing using Wemos as a microcontroller, Android as interface and firebase for its storage media. This research uses $d h t 11$ to monitor room temperature and humidity, sound sensor to know whether baby cry or not and use Load Cell to check if the baby is still in the box or not. This research also add water sensor to provide information when the baby wets.

\section{Research Methods}

Based on research the appropriate method used in this study uses the R \& D model Borg and Gall [6]. Stages performed are:

a. Information gathering

This stage is done by study literature and interviews. Study literature done through books and journals. Interviews were conducted on parents who have a toddler in the area of Wonodri urban village in Semarang. From this interview will be known the problem occurred.

b. Determination

This stage was done by finding the formulation of the problem to determine the research purpose and plan the product will be made.

c. Planning

The hardware and software design was done in this step by selecting Wemos, Sound sensor, dh11 sensor, Load Cell, Water sensor and Modem Wi-Fi as the hardware and using the software called Android as an interface and firebase as a storage medium.

d. Preparation of Initial Design of the Product

At this stage, the schematic hardware products were determined by using fritzing software, making block diagrams of each part and the workflow creation of a smart baby box and UML for Android creation.

e. Testing the early stages

At this stage, the applications and the design of the baby box were tested to know whether the sensor can run in accordance with the initial planning by knowing the time needed to deliver data from Box to Android. If this stage was not succeeded, the procedure would be repeated to its prior stage.

f. Field tests

The experiments carried out on the residents who have babies under the age of 1 year This is the step of testing the baby box in the real field. The interviews with those citizens were carried out, and the products have been tested at the same time. As the data obtained, if there were constraints in the products, the experiments would return to the stage of Preparation of Initial Design of the Product.

g. Conclusion Taking.

From the information obtained from the previous stage it can be inferred whether the product is not feasible to use or not.

\section{Result and Discussion}

\subsection{Internet of Things (IoT)}

Internet of things (IoT) is a new thing in the field of computers. Its main vision is to connect communication with devices such as Radio-Frequency Identification (RFID) tags, sensors, actuators, through various wireless communication standards (Wi-Fi, NFC, etc.)[7]. Through that communication, objects can interact with each other and work together to achieve the common good. In other words, loT can be called "a worldwide network of interconnected objects that can be addressed uniquely, based on standard communication protocols". The Internet of 
Things allows people and things to connect Anytime, anywhere, with Anyone and Anyone, ideally using any path or network and any Service[8].

\subsection{Wemos}

Wemos is a module based on ESP-8266 microcontroller and provides 4 MB flash. The GPIO (General-purpose input/output) nine pins make this board suitable for a large IOT (internet of things) target audience. This is a very good Microcontroller Unit (MCU) that can be programmed with Arduino IDE or Nodemcu. It has micro USB for automatic programming and can also be programmed using OTA (Over The Air)[9]. One side board features ESP8266 module and the other side has $\mathrm{CH} 340$ serial to USB chip, and reset button and PCB antenna. Even compatible with Android and iPhone. It has the ability to use external Antenna and USB CP2104 to UART IC. Because Wemos uses ESP-8266, Wemos has the function of a WIFI module that is designed to be able to exchange data using the IEEE 802.11 specification which can be connected to MIFI for communication with other devices using the $2.4 \mathrm{GHz}$ frequency[10].

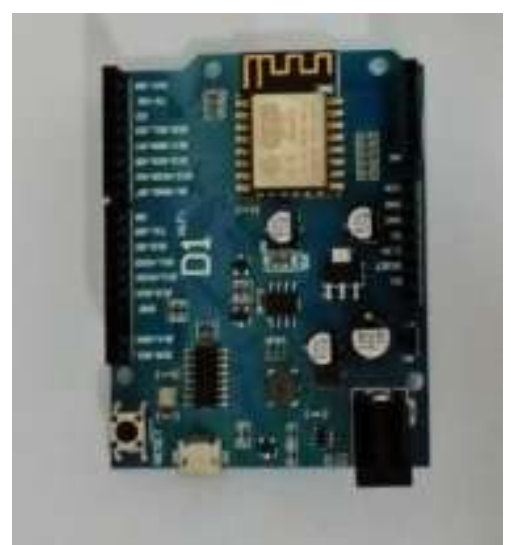

Figure 1. Wemos D1

\subsection{FC-04 Sound Sensor}

The FC-04 sound sensor module can detect the surrounding sound intensity, identify the presence or lack of sound with the sensitivity of the $48 \mathrm{~dB}-52 \mathrm{~dB}$ microphone. This sensor changes the amount of sound into electricity. Incoming signal will be processed and produce a condition 0 or 1 . Sound received by condenser will be sent to preamp microphone (microphone amplifier). In addition, the sensitivity of the sound sensor can also be adjusted, the more condensers used in the preamp then the better the sensitive sensors[11].

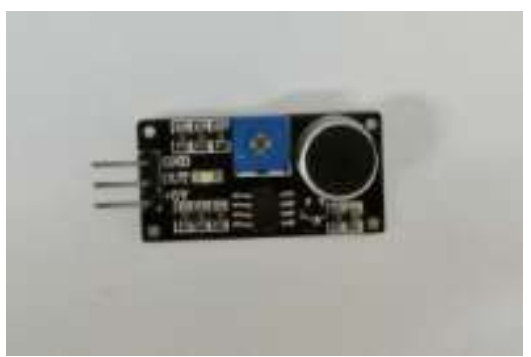

Figure 2. FC-04 sound sensor

\section{4. dht11 Sensors}

Sensors that serve to measure temperature and humidity are $d h t 11$ sensors. This sensor has a humidity range that can be measured between $20 \%$ to $90 \% \mathrm{RH}$ and has an accuracy of $\pm 4 \%$ $\mathrm{RH}$ and has a sensitivity of $1 \% \mathrm{RH}$. The dht11 sensor is a composite that is calibrated with a digital signal output of temperature and humidity, has temperature and humidity sensing technology, to ensure that the product has high reliability and long-term stability. Usually in the application for testing and inspection of equipment, consumption, automotive, automatic control, 
data logger, weather station, house wares, moisture regulator, medical and other moisture measuring and control devices[12].

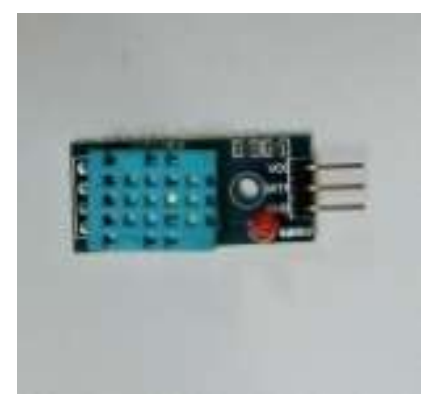

Figure 3. dht11 Sensor

\subsection{Sensor Load Cell}

Load cell sensors are sensors designed to detect the pressure or weight of a load. The load cell sensor is generally used as a major component of the digital weighing system and can be applied to a scale bridge that weighs the weight of the raw material truck, the measurements made by Load Cell using the principle of pressure[13].

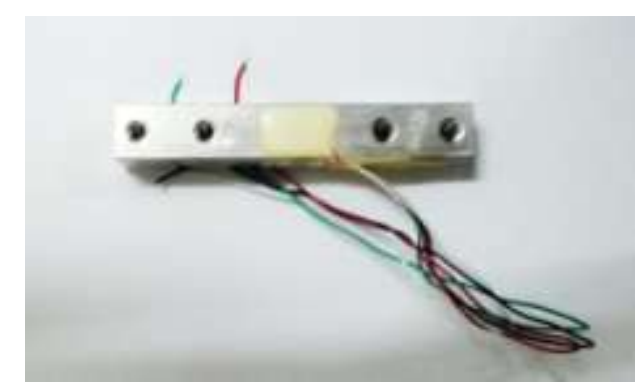

Figure 4. Load Cell Sensor

\subsection{Water Sensor}

Water Sensor is a sensor that can detect the presence of water, and also can be used as a detector of rainfall, water level detection and even leakage of liquid. In addition, this sensor is also used to measure the level, volume, and detect the presence or absence of water. This sensor works when an open circuit between the ground of the power source is contacted with water. This sensor contains $1 \mathrm{M} \Omega$ pull-up resistor which will pull the sensor to detect the value of a drop of water contact to the open circuit in the sensor, when the water is touched by the surface of the open circuit it will be directly connected to the ground. This circuit will function by using a digital pin on the Arduino to detect the presence of water and can use an analog pin to detect the amount of water induced by an open circuit with ground and sensor[14]. 


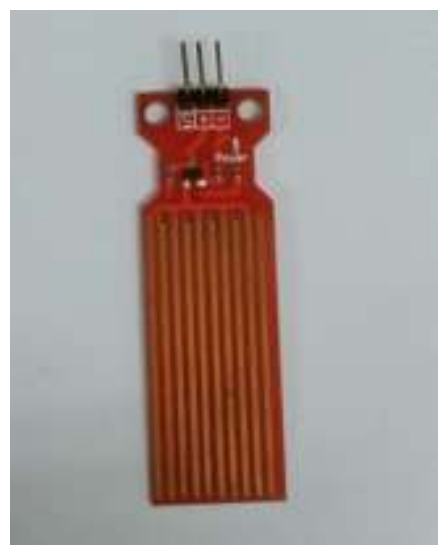

Figure 5. Water Sensor

\subsection{Literature Review}

According to research of the room comfort level is very much influenced by high and low temperature, therefore it is very necessary to monitor the room comfort level by using a webbased interface so that a lot of space can be monitored from one peripheral and can controlled through remotely using a Local Area Network. The weakness of this research, sensor can only be monitored from one building and computer based so that mobility will be lacking[8].

In another journal, it is said that the process of sending data using wireless technology will make it all easier and more efficient because monitoring using wireless technology causes the supervision process to be faster without being in a location close to the object monitored. In his research, he used to monitor the condition of soil moisture using Xbee and Arduino Mega. The lack of this research is that the price of Xbee is still too expensive for mass production, while its usage can be accessed from a long distance so it is very profitable[15].

K.N.Khamil said monitoring on babies is very important, in his research conducted for a system of reminders of the presence of babies in the car using Arduino and RF waves. The system has connected to the parents' smart phones. When parents are far from the box of babies in the car, the system automatically gives a danger sign through the parent's smart phone which contains a warning that the baby is left in the car. However, his system has a deficiency when the smart phone runs out of battery, the warning system will not be read and because it uses RF waves, similar signal collision disturbances will be possible[11].

\subsection{Firebase}

Firebase is the latest Cloud services at the moment, as Firebase's backend provides cool real time database services for every platform, both Web, Mobile Android/IOS or any other platforms that support the firebase API[1]. With this API we can sync data to multiple clients and store Firebase cloud and REST API using the Server-Sent Events SSE protocol, which will make an HTTP connection to receive push notifications from the server. The use of firebase in this study is due to the ease of sending data for notifications on Android in real time[1]. 


\subsection{Schematic and Result}

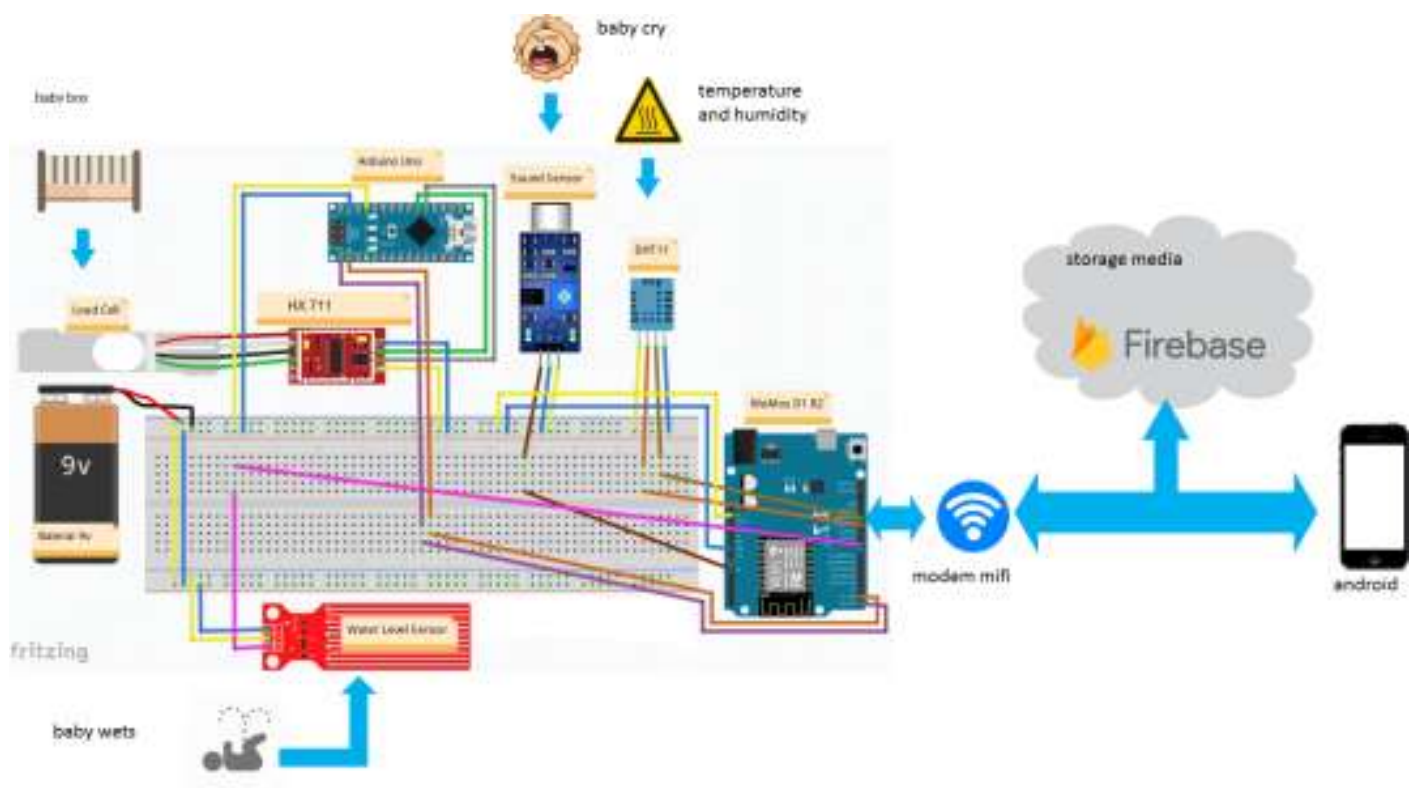

Figure 6. Schematic of an Intelligent Baby Box Circuit

Figure 6 is a schematic of an Intelligent Baby Box Circuit, where there are dht11 sensors, load cell, water sensor, and sound sensor as inputs, while for voltage source in batteries 9V. All conditions in the baby box will be sent through the modem Wi-Fi connected with Wemos. When the data sent on the internet will be stored on the firebase later on the data will be taken by Android.

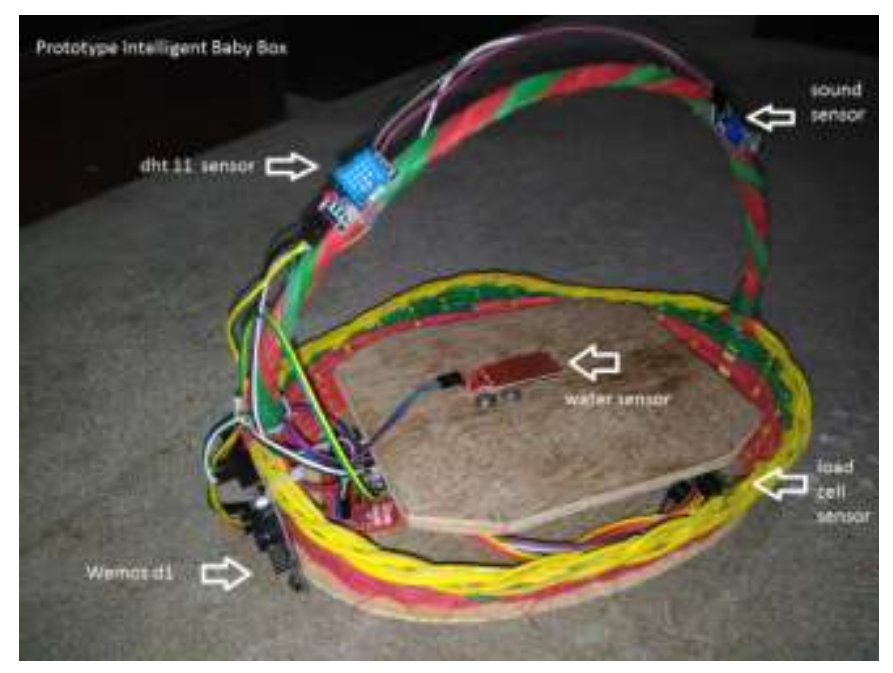

Figure 7. Design of an Intelligent baby box

Figure 7 is a design of an Intelligent baby box using a sound sensor, dht11, water sensor and load cell using Wemos microcontroller, which later will be connected to MIFI so that data received can be sent to firebase which at the end it will be accessed by Android. 


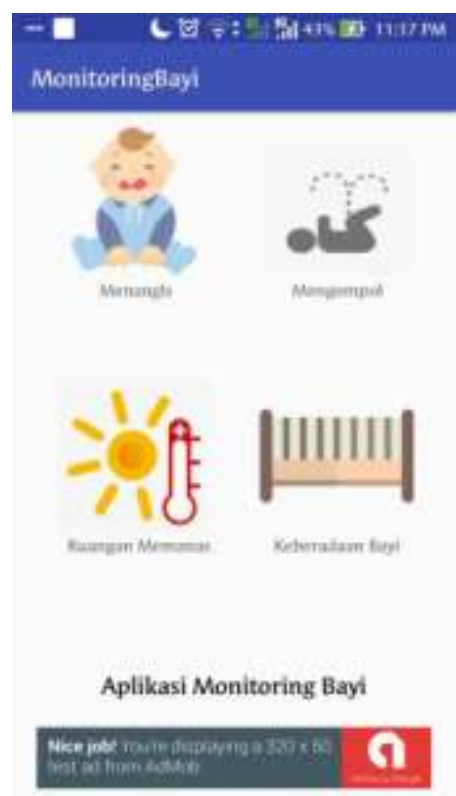

Figure 8. Main Interface of android

Figure 8 above shows that Menangis is the button to know if the baby is crying or silent, Mengompol is the button to monitor the baby in the baby box when wet or dry condition, Ruangan Memanas is a button to monitor the temperature and humidity the room more than $30^{\circ} \mathrm{C}$ or not, the Keberadaan Bayi is the button to monitor baby is there in a box or not.

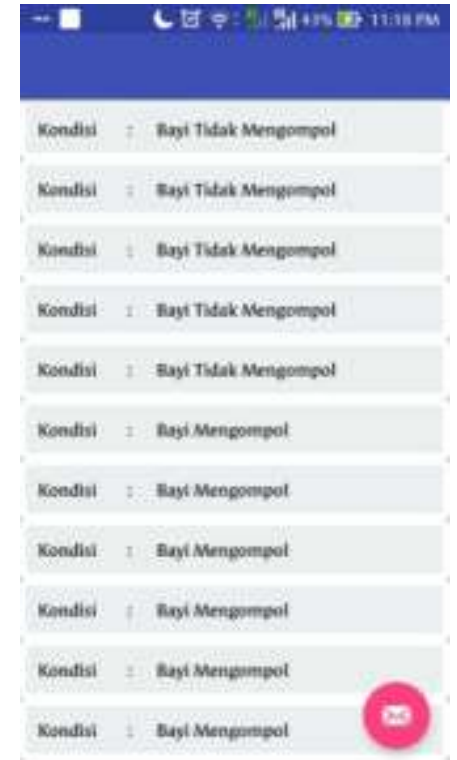

Figure 9. Data View of water sensor

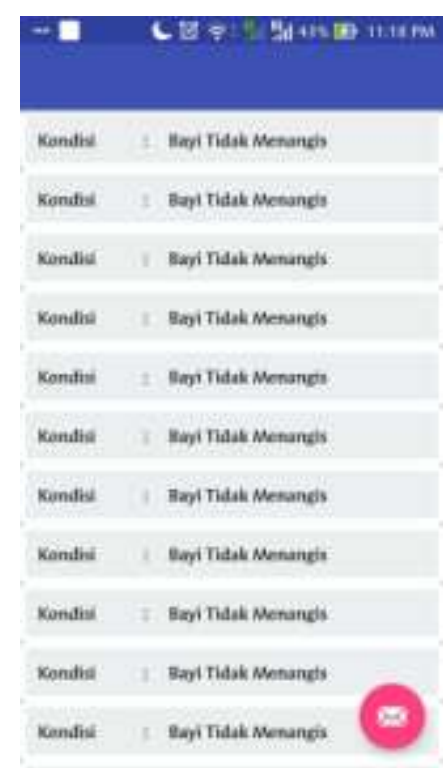

Figure 10. Data View of a sound sensor

Figure 9 is data view of water sensor, Bayi Mengompol means baby box in wet condition and Bayi Tidak Mengompol means baby box in a dry condition, meanwhile in figure 10 is data view of a sound sensor, Bayi Tidak Menangis means baby in silent condition and Bayi Menangis means baby is crying. When the wet condition is on and the water sensor detects it, there will be a notification Bayi Mengompol This can be seen in figure 9 if the dry condition is on and water sensor does not detect water then the notification will be written Bayi Tidak Mengompol. Whereas, in the condition when the baby is sleeping so that the sound sensor does not detect the baby's cries, the notification will be written Bayi Tidak Menangis on the 
contrary, when the baby cries and the sensor detects the crying, notification will be written Bayi Menangis this can be seen in figure 10.

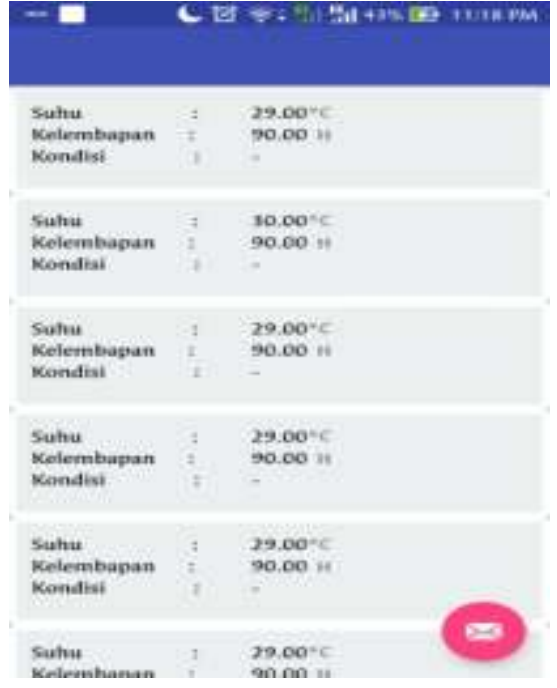

Figure 11. Data View Sensor dht11

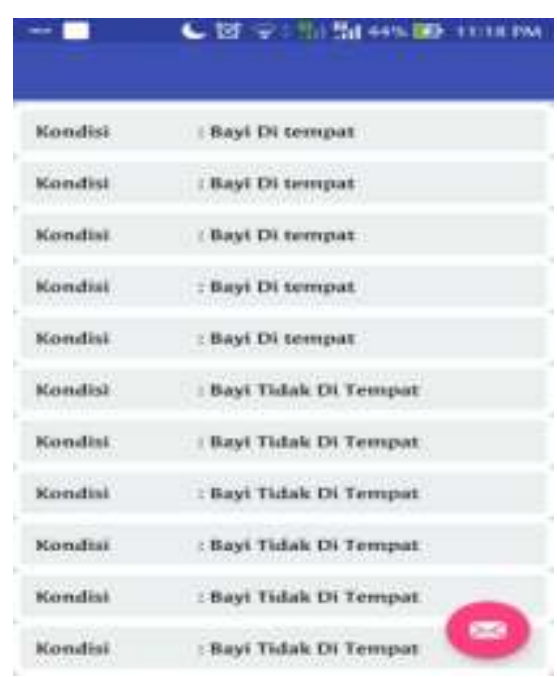

Figure 12. Data View LoadCell Sensor

Figure 11 above explains Suhu is temperature, Kelembapan is humidity and Kondisi means the condition of the room where the baby box is put down. The condition of temperature is up to $30^{\circ} \mathrm{C}$. The status will change to a hot condition when dht11 sensor detects a temperature above $30^{\circ} \mathrm{C}$, then the notification will be written in Kondisi Panas, if not hot condition then it will not be written anything as seen in figure 11 . While the presence of a baby is detected by a load cell sensor that detects the baby's weight. When the sensor is turned on and the weight changes below $2 \mathrm{~kg}$, there will be a notification Bayi Tidak Di Tempat but when the load cell sensor detects the baby, there will be a notification Bayi Di Tempat. This notification can be seen at figure 12 .

Table 1. The result of testing sound and water sensor

\begin{tabular}{cccccc}
\hline No & $\begin{array}{c}\text { Data } \\
\text { Appears } \\
\text { On } \\
\text { Android }\end{array}$ & \multicolumn{2}{l}{ Sound Sensor } & \multicolumn{2}{l}{ Water Sensor } \\
\cline { 3 - 6 } & & & & & \\
\hline 1 & Yes & Yes & No & Yes & No \\
\hline 2 & Yes & Yes & No & Yes & No \\
\hline 3 & Yes & Yes & No & No & Yes \\
\hline 4 & Yes & Yes & No & Yes & No \\
\hline 5 & Yes & No & Yes & No & Yes \\
\hline 6 & Yes & Yes & No & Yes & No \\
\hline 7 & Yes & No & Yes & Yes & No \\
\hline 8 & Yes & No & Yes & No & Yes \\
\hline 9 & Yes & No & Yes & No & Yes \\
\hline 10 & Yes & No & Yes & No & Yes \\
\hline & & & & &
\end{tabular}

In table 1 are the results of the test done several times using a sound sensor, water sensor and Android. This test was done by giving fluid which similar with baby pee in the baby box to the position of the baby's bed and giving a sound that is similar to the baby's voice. When the sensor detects it, data will be sent to Android. The test connected baby box with Android using internet connection through MIFI which can be taken anywhere. On the test that was conducted 10 times, data can be received from Wemos into Android. The data of crying or silence condition appears in figure 10. Bayi Menangis means cry in figure 10 and Bayi Tidak 
Accredited B by RISTEKDIKTI Decree No. 51/E/KPT/2017

Menangis means silent in figure 10. While on the sensor Water, the data condition of Wet, meaning Bayi Mengompol and Dry, meaning Bayi Tidak Mengompol can be received in the Android as shown in Figure 9

Table 2. The Result of testing dht11 and Loadcell sensor

\begin{tabular}{cccccc}
\hline No & $\begin{array}{c}\text { Data } \\
\text { Appears } \\
\text { On }\end{array}$ & dht 11 sensor & \multicolumn{2}{c}{ Sensor LoadCell } \\
\cline { 3 - 6 } & Android & Hot & Normal & $\begin{array}{c}\text { baby in } \\
\text { the baby } \\
\text { box }\end{array}$ & $\begin{array}{c}\text { baby not } \\
\text { in the } \\
\text { baby } \\
\text { box }\end{array}$ \\
\hline 1 & Yes & No & Yes & No & Yes \\
\hline 2 & Yes & Yes & No & No & Yes \\
\hline 3 & Yes & Yes & No & No & Yes \\
\hline 4 & Yes & No & Yes & Yes & No \\
\hline 5 & Yes & Yes & No & Yes & No \\
\hline 6 & Yes & No & Yes & No & Yes \\
\hline 7 & Yes & Yes & No & No & Yes \\
\hline 8 & Yes & Yes & No & Yes & No \\
\hline 9 & Yes & No & Yes & Yes & No \\
\hline 10 & Yes & No & Yes & Yes & No \\
\hline
\end{tabular}

In Table 2 are the results of the test using dht11 sensor and load cell sensor. The test was conducted 10 times and managed to appear in Android. When the temperature hits above $30^{\circ} \mathrm{C}$ it means hot conditions and if it is below $30^{\circ} \mathrm{C}$, it means normal conditions. For Load Cell sensors using a weight limit of more than $2 \mathrm{~kg}$, it means that there is a baby in the baby's box if it shows above $2 \mathrm{~kg}$, and if the sensor detects below $2 \mathrm{~kg}$, that means the baby is not in place and condition. The temperature condition, which is hot or normal, can be seen in figure 11. Meanwhile Load Cell shows Bayi di tempat when the baby is placed in the box and is Bayi tidak di Tempat when the baby is taken and load cell sensor read below $2 \mathrm{~kg}$ can be seen in figure 12 .

\section{Conclusion}

This research, the process of sending data from hardware to android using loT technology (Internet of Things) was successfully done and data can be received and stored smoothly on the Android. All of the 10 times experiments performed either in wet or dry conditions for water sensors, crying or silent for sound sensors, there are baby on the box or not for load cell sensors as well as dht11 sensors that display the temperature and humidity of air, were successfully transmitting data from the hardware into the firebase database. When the data enters the firebase and provides notifications on the Android, parents or caregivers can find out the baby's condition, especially when crying so the baby's cry can be quickly known so that Baby Distressed Tantrum at baby can be prevented[8].

Compared to what Mandarani do, the strength of this research is that the data in this study can be viewed and obtained through Android so that it can be done over long distances. This is different from the Mandarani's research which is constrained in one building. Whereas when compared to the research conducted by S.Rodriguez in obtaining the similarity of data accessed through long distances and easier way, the only difference is the tools used. The S.Rodriguez research used Xbee while this research used Wemos which is cheaper than Xbee. In the research done by K.N.Khamil, where he monitored the baby in the car using RF waves so that the distance obtained is very limited because of using RF Wave. In a different way, this research used an loT that's not limited in distance because the use of the internet, besides the use of RF waves is very vulnerable to collisions with the same signal channel.

Accordingly, it can be concluded that the ability to receive data remotely and anywhere using loT technology is an advantage of this system. Users can find out the condition of the baby box at any time when the system is turned on and connected to Wi-Fi so that expected Baby 
Distressed Tantrum can be minimized and the baby's health will be maintained. This system is very dependent on the existence of the Internet, thereby becoming one of its weaknesses.

\section{References}

[1] L. Luceri et al., "VIVO: A secure, privacy-preserving, and real-time crowd-sensing framework for the Internet of Things," Pervasive Mobile Computing, vol. 49, pp. 126$138,2018$.

[2] J. Santos et al., "Author' s Accepted Manuscript An loT-based Mobile Gateway for Intelligent Personal Assistants on Mobile Health Environments," Journals of Network and Computer Applications, vol. 71, no. agustus 2016, pp. 194-204, 2016.

[3] D. Sasmoko and Y. A. Wicaksono, "Implementasi Penerapan Internet of Things ( loT ) Pada Monitoring Infus Menggunakan Esp 8266 dan Web Untuk Berbagi Data," Jurnal Ilmiah Informatika, vol. 2, no. 1, 2017.

[4] D. Sasmoko and A. Mahendra, "Rancang Bangun Sistem Pendeteksi Kebakaran Berbasis IoT Dan Sms Gateway Menggunakan Arduino," Simetris, vol. 8, no. 2, pp. 469476, 2017.

[5] K. sun Jin, J. L. Houston, R. Baillargeon, A. M. Groh, and G. I. Roisman, "Young infants expect an unfamiliar adult to comfort a crying baby: Evidence from a standard violationof-expectation task and a novel infant-triggered-video task," Cognitive Psychology, vol. 102, no. December 2017, pp. 1-20, 2018.

[6] A. Suyetno, D. Kustono, and D. A. Sudjimat, "Pneumatic control system simulation based a PLC micro in mechatronics courses," in AIP Conference Proceedings, 2016, vol. 1778, pp. 030035-1-030035-8.

[7] A. Deva, S. Illahi, A. Bella, S. Hadiyoso, and S. Aulia, "Safety Helmet Implementation with Centralized Information System on Remote Monitoring Applications," Lontar Komputer Jurnal Ilmiah Teknologi Inormasi, vol. 9, no. 1, 2018.

[8] P. Mandarani, "Perancangan Dan Implementasi User Interface Berbasis Web Untuk Monitoring Suhu, Kelembaban Dan Asap Pada Ruangan Berbeda Dengan Memanfaatkan Jaringan Local Area Network," Jurnal TEKNOIF, vol. 2, no. 2, pp. 37-42, 2014.

[9] S. Chaudhary, V. Bhargave, S. Kulkarni, P. Puranik, and A. Shinde, "Home Automation System Using WeMos D1 Mini," International Reseach Journal of Engineering Technology, vol. 5, no. 5, pp. 4238-4241, 2018.

[10] S. Rukhmode, G. Vyavhare, S. Banot, and A. Narad, "IOT Based Agriculture Monitoring System Using Wemos," in International Conference On Emanations in Modern Engineering Science and Management, 2017, no. March, pp. 14-19.

[11] K. N. Khamil, S. I. A. Rahman, and M. Gambilok, "Babycare alert system for prevention of child left in a parked vehicle," ARPN Journal of Engineering and Applied Sciences, vol. 10, no. 22, pp. 17313-17319, 2015.

[12] O. Bamodu, L. Xia, and L. Tang, "An indoor environment monitoring system using lowcost sensor network," in Energy Procedia, 2017, vol. 141, pp. 660-666.

[13] R. N. Naik, P. S. N. Reddy, S. N. Kishore, and K. T. Kumar Reddy, "Arduino Based LPG gas Monitoring \&amp; Automatic Cylinder booking with Alert System," IOSR Journal of Electronics and Communication Engineering, vol. 11, no. 04, pp. 06-12, 2016.

[14] P. S. Lalwan, M. K. Khurana, S. J. Khandare, O. U. R. Ansari, and S. B. Pokle, "IoT Based Industrial Parameters Monitoring and Alarming System using Arduino - A Novel Approach," International Journal of Engineering Science and Computing, vol. 8, no. 4, pp. 17305-17308, 2018.

[15] S. Rodríguez, T. Gualotuña, and C. Grilo, "A System for the Monitoring and Predicting of Data in Precision Agriculture in a Rose Greenhouse Based on Wireless Sensor Networks," Procedia Computer Science, vol. 121, no. 8-10 November 2017, pp. 306313, 2017. 